\title{
Application of Metagenomic Next-Generation Sequencing in The Diagnosis and Treatment Guidance of Pneumocystis Jirovecii Pneumonia in Renal Transplant Recipients
}

\author{
Feng Zhang \\ Central South University \\ Jia Chen \\ Central South University \\ He Huang \\ Hunan International Travel Health Center \\ Rangjiao Liu \\ Sansure Biotech INC. \\ Xiaomei Ren \\ Biotech \\ Qiquan Wan ( $\sim 13548685542 @ 163 . c o m)$ \\ Central South University
}

\section{Research Article}

Keywords: Pneumocystis jirovecii pneumonia, renal transplantation, diagnosis, metagenomic next-generation sequencing, $\beta$-D-glucan assays

Posted Date: February 22nd, 2021

DOI: https://doi.org/10.21203/rs.3.rs-144092/v2

License: (1) This work is licensed under a Creative Commons Attribution 4.0 International License. Read Full License

Version of Record: A version of this preprint was published at European Journal of Clinical Microbiology \& Infectious Diseases on April 21st, 2021. See the published version at https://doi.org/10.1007/s10096-021-04254-x. 


\section{Abstract}

Purpose: Pneumocystis jirovecii pneumonia (PJP) is difficult to be diagnosed, so this study explored if PJP could be diagnosed by metagenomic next-generation sequencing (mNGS) and if mNGS could guide the therapy of PJP.

Methods: mNGS successfully diagnosed 13 out of 14 PJP recipients with 11 through peripheral blood samples, verified by PCR. Ten non-PJP recipients were enrolled as the control group.

Results: Blood tests revealed a high $\beta$-Dglucan (BDG) level in all recipients with PJP during the hospitalization. Four (28.6\%) of 14 PJP patients were infected with cytomegalovirus simultaneously, while 8 (57.1\%) suffered from a combined infection caused by Torque teno virus. Five (35.7\%) of 14 cases died of PJP or the subsequent bacteremias/bacterial pneumonia with a longer interval between the onset and diagnosis of/the available therapy against PJP than survival cases. Univariate analysis of Characteristics between PJP and non-PJP recipients revealed that BDG assays was higher at the admission in PJP group $(P=0.011)$.

Conclusions: This present study supports the value of mNGS detection of blood sample in diagnosing PJP, which could assist clinical decision for therapy against PJ and improve outcome of PJP. The study also highlights the sensitivity of BDG assays. Cytomegalovirus and Torque teno virus infections often occur at the same time of PJP, thus can be alerts of PJP.

\section{Introduction}

Pneumocystis jirovecii pneumonia (PJP) is a serious and even critical opportunistic infection, which usually occurs in renal transplant recipients (RTRs) who are prone to respiratory infections, accompanied by multiple infections [1].PJP cases have been reported frequently in solid organ transplant recipients, particularly in RTRs [2-5].

Precise and early diagnosis is important for the prognosis and survival of immunocompromised, critically ill RTRs. Nevertheless, as Pneumocystis jirovecii (PJ) cannot be reliably grown in vitro, PJP is diagnosed mainly through microscopic detection in respiratory specimens followed by staining methods, which generally shows low sensitivity and specificity $[3,6]$. Detection of serum $\beta$-D-glucan (BDG) is sensitive but lack specificity [7]. Polymerase chain reaction (PCR)-based diagnostic assays have significantly improved the sensitivity and specificity whereas its commercial kits have not yet been approved for clinical use in China [8].

Recently, metagenomic next-generation sequencing (mNGS), as an all-in-one diagnostic tool, has been successfully used for various infectious diseases, showing a higher detection rate of PJP compared to conventional methods [1,9-11]. Of note, 4 cases of PJP were reported to be confirmed by mNGS in peripheral blood rather than respiratory samples $[1,12]$. Although mNGS can diagnose PJP rapidly and noninvasively in immunocompromised patients, it was used to diagnose PJP only in 2 RTRs, awaiting further evaluation for its value [1,2]. Herein we studied 14 cases of RTRs with PJP and 10 non-PJP RTRs predominantly identified by mNGS of blood samples rather than bronchoalveolar lavage fluid (BALF)/sputum to further explore its accuracy.

\section{Materials And Methods}

\section{Study Design and Study Subjects}

This was a single-center retrospective cohort study from the Third Xiangya Hospital, Central South University, China. All renal transplant recipients with a diagnosis of pneumonia who admitted to our center from March 1, 2019 to October 31, 2020 were enrolled, divided into two groups: PJP or non-PJP. Clinical data of renal transplant recipients diagnosed with PJP or non-PJP mainly by mNGS and confirmed by PCR were analyzed. All patients included were at least 18 years old at renal transplantation. Trimethoprimsulfamethoxazole (at doses of $80 \mathrm{mg}$ and $400 \mathrm{mg}$, respectively, once daily, for at least four months) was given as a prophylaxis to all recipients enrolled after renal transplantation. No organs from executed prisoners were used. This retrospective non-interventional study involved 14 RTRs with PJP and 10 non-PJP RTRs, which was approved by the Research Ethics Committee at the Third Xiangya Hospital of Central South University, consistent with principles in the Declaration of Helsinki (protocol no. IRB-2020-S636). The ethics committee waived the need for informed consent.

\section{Routine Immunosuppression}

Induction immunosuppression consisted of basiliximab and/or antithymocyte globulin and methylprednisolone ( $0.5 \mathrm{~g}$ given during the operative procedure, 200-250mg on postoperative day 1-3). Maintenance immunosuppression included mycophenolate mofetil, 
prednisone and a calcineurin inhibitor, tacrolimus or cyclosporin A.

\section{Sample Collection and Processing}

Routine cultures for bacteria and fungi were performed for all samples. A total volume of $8 \mathrm{ml}$ blood samples was collected in BD vacutainer plasma preparation tubes for viral and microbial analysis using mNGS, or $3 \mathrm{ml}$ BALF/sputum samples were provided for mNGS detection. Blood samples were stored at room temperature and BALF/sputum samples were store with ice bags at 2-8 degrees Celsius.

\section{DNA Extraction, Library Construction and Sequencing}

Viscous BALF or sputum samples were homogenized with normal saline. Blood samples were centrifuged at $1600 \mathrm{rpm}$ and BALF/sputum samples were centrifuged at $12000 \mathrm{rpm}$ for 10 minutes at $4^{\circ} \mathrm{C}$ to eliminate debris. Pyrolysis liquid $\mathrm{GHL}$ was added to release total DNA for BALF/sputum samples. Cell-free DNA from plasma and total DNA from BALF/sputum samples was extracted and purified using a Nucleic Acid Extraction (DNA) or Purification Kit (Sansure Biotech, Magnetic beads method, S1005). Extracted DNA was measured by Qubit dsDNA HS Assay Kits (Thermo Fisher Scientific, Art. No. Q32854), and the total mass of DNA needs to be more than $1 \mathrm{ng}$ as a quality control. The total DNA was further fragmented using dsDNA fragmentase. DNA libraries for sequencing were then constructed. The $5^{\prime}$ end of DNA fragment was phosphorylated and a Da tail was added at the 3' end, following adapters were attached to the nucleic acid templates for subsequent sequencing and sample identification. Sequencing libraries were pooled with environmental control samples, which were used to monitor sample-to-sample contamination and were processed alongside the test samples in every batch. Pooled sample libraries up to 18 libraries per batch were multiplexed and sequenced on IIlumina NextSeq500 sequencers using a 75-cycle single-end, single index sequencing kit.

\section{Bioinformatic Analysis}

High-quality sequencing data were generated by removing low quality and adapter sequences using Trimmomatic. To remove the human original sequences, the cleaning reads were mapped to the human genome (containing GRCh38 and Homo sapien clone satellite sequences) using Burrows-Wheeler Alignment tool. Subsequently, the remaining data were aligned to the bacterial, viral, fungal and parasite databases using Burrows-Wheeler Alignment tool. The reference databases were downloaded from NCBI RefSeq (ftp://ftp.ncbi.nlm.nih.gov/genomes/refseq) and Genbank (ftp://ftp.ncbi.nlm.nih.gov/genomes/genbank). The bacterial database contained 6600 different species, the fungal database contained 980 different species, the viral database contained 5000 different species, parasite database contained 220 different species. The mapping standard criteria included: 1) continuous match numbers were more than 50bp. 2) mismatch numbers were less than $3 b p$.

The mapped reads were aligned to the NCBI-nt database using Blastn for verification and filtration. We further calculated the coverage and abundance of species using Samtools. Some non-specific reads would be filtered if they were mapped to different genus and different species within the standard mapping criteria. Only the reads mapped to unique species could be classified to the species level. If one read was mapped to a unique genus and different species, it would be classified to the genus level. According to the classification results, we obtained the information of genus and species for the tested samples.

\section{Criteria for Reporting a Positive mNGS Result}

The database curated from books was used for pathogenic comments, which was after the positives were selected [13,14]. The background database (containing species with detection rate greater than $50 \%$ in all whole blood samples) and the environmental control were used for filtering out the environmental contaminations. The criteria for reporting positive pathogens would be as follows:

1. For fungi and viruses, pathogens with the mapping read number greater than or equal to 3 and the confidence level more than $99 \%$ will be selected;

2. For bacteria (Mycobacterium tuberculosis excluded) and parasites, the pathogens will be reported if the mapping read number was in the top 5 of bacteria or parasitic list and not in the background library [15];

3. Mycobacterium tuberculosis would be considered positive if at least 1 read was mapped to either the species or genus level, due to the difficulty of DNA extraction and low possibility of contamination [16];

\section{PCR Validation}


Sterile centrifuge tubes were used to collect blood, sputum or alveolar lavage fluid from patients. The sample volume after liquefaction should not be less than $1 \mathrm{~mL}$. The sample to be tested could be placed at $2^{\circ} \mathrm{C} \otimes 8^{\circ} \mathrm{C}$ for less than 72 hours. Long-term storage should be placed under the condition of $\leq-20^{\circ} \mathrm{C}$ to avoid repeated freezing and thawing. The specimens were transported in a curling pot with ice or a foam box with ice sealed for transportation.

$200 \mu \mathrm{L}$ of the sample to be tested were put into a $1.5 \mathrm{~mL}$ centrifuge tube, to perform nucleic acid extraction using the nucleic acid extraction or purification reagent (S1006, Sansure Biotech ) according to its instruction.

The PCR validation was carried out using the pneumocystis nucleic acid detection kit (PCR-fluorescent probe method囚Sansure Biotech). The fluorescence detection used the ROX channel to detect human pneumocystis, and the CY5 channel to detect the internal standard.

If the ROX channel detected a typical S-type amplification curve, and $\mathrm{Ct} \leq 40$, the human pneumocystis was positive. If $\mathrm{Ct}>40 \mathrm{or}$ no $\mathrm{Ct}$, it was negative. If the internal standard did not detect $\mathrm{Ct}$ or $\mathrm{Ct}>40$ in the CY5 channel, which meant that the concentration of the test sample was too low or there were interfering substances that inhibited the reaction, the experiment was repeated again.

\section{Statistical Analysis}

All analyses were performed using the statistical package SPSS for Windows, version 22.0 (IBM Corporation, Armonk, NY, USA). Results were listed as mean $( \pm S D)$ for continuous variables. Univariate analysis was applied to inspect the distinction of characteristics between PJP and non-PJP groups. Continuous variables were compared using Student's unpaired t-test. Categorical variables were compared with Pearson's $\chi^{2}$ test or Fisher's exact test. Statistical tests were two-tailed and statistical significance was defined as $P<0.05$.

\section{Results}

There were 14 RTRs diagnosed with PJP in our center from March 1, 2019 to October 31, 2020. The baseline characteristics of the 14 PJP recipients enrolled were presented in Table 1. Time interval between renal transplantation and PJP was less than 3 years. The median age was 37.6 (range, 19-54) years. Ten participants were males. Seven recipients had renal insufficiency and 2 suffered from diabetes at the admission. All 14 recipients received chest high-resolution computed tomography scans at the admission, suggesting reticular and/or ground-glass opacities pulmonary infiltrates without pleural effusion, consistent with characteristics of interstitial pneumonia. During hospitalization, 7 recipients progressed to severe acute respiratory distress syndrome (ARDS) and 1 occurred acute renal failure. All patients were initially prescribed 3 maintained immunosuppressants (tacrolimus/cyclosporin A + mycophenolate mofetil + glucocorticosteroids), and additional agents of basiliximab and/or antithymocyte globulin were administrated as an induction therapy in 10 recipients.

Five of 14 (35.7\%) cases died: one each died of PJP, the subsequent bacterial pneumonia caused by A.baumannii, and the subsequent bacteremia due to A.baumannii, and 2 died of the subsequent bacteremia owing to K.pneumoniae. The mean time interval between the onset and the diagnosis of PJP in these five died patients was 24 (ranged from 9 to 40) days, with 16.4 (ranged from 7 to 35) days of the mean interval between the onset of PJP and the available therapy against PJP. The corresponding intervals were only 9 (ranged from 6 to 18) and 4.9 (ranged from 2 to 11) days in 9 survival recipients. Treated with trimethoprim-sulfamethoxazole and a certain time period of caspofungin for 15-49 days, these 9 RTRs were cured and discharged. Laboratory tests and mNGS results obtained from the 14 RTRs with PJP were listed in Table 2. We conducted mNGS in 21 samples including 16 peripheral blood and 5 respiratory samples collected from enrolled recipients. The respiratory samples consisted of 3 BALF and 2 sputum samples. All the cases were receiving antibiotics at the time of sample collection for mNGS testing, with 10 receiving other antifungal agents at the same time and 1 receiving agents actively against PJ as long as 11 days. Two patients had leukopenia (white blood cell count $<4000 / \mu \mathrm{L}$ ) and 6 had severe lymphopenias (absolute lymphocyte count $<500 / \mu \mathrm{L}$ ) at baseline. C-reactive protein was more than $60 \mathrm{mg} / \mathrm{L}$ in $57.1 \%$ of patients (8/14) while procalcitonin was relatively low in all patients (ranged from 0.019 to $1.567 \mathrm{ng} / \mathrm{mL}$ ) at baseline. All 14 patients underwent 58 times of BDG assays with $50(86.2 \%)$ times being positive. Eight negative results appeared either early in the onset of the disease $(n=1)$ or near recovery $(n=7)$. Among 50 times of $B D G$ assays, 29 times were more than $400 \mathrm{pg} / \mathrm{ml}$.

Thirteen (92.9\%) of 14 RTRs were diagnosed with PJP by mNGS, verified by PJ PCR, consistent with patients' clinical manifestations and radiological findings. Eleven of 14 patients provided peripheral blood samples. Of them, 2 simultaneously provided respiratory samples. The other 3 cases used BALF or sputum samples. Notably, the PJ sequencings reads fluctuated as the infection state changed in Case 5 who underwent five times of mNGS detection of blood sample and eventually no PJ was detected before his discharge. 
Microscopic examination of stained sputum found PJ in 1 case. Ct values of PJ PCR of these 13 recipients with mNGS positive ranged from 25.14 to 38.42. The Ct value of the remaining 1 PJP recipient was more than 40 .

Mixed-infections were observed in 10 PJP recipients. mNGS identified cytomegalovirus in 4 cases(3 of them cytomegalovirus replication confirmed by standard PCR), Torque teno virus in 8 cases, and Candida parapsilosis in 2 cases, and Pseudomonas putida, Haemophilus parainfluenzae, Mycoplasma orale, BK virus, Human polyomavirus 8, Human polyomavirus 1, and Human coronavirus $229 \mathrm{E}$ in 1 case each. Furthermore, A.baumannii was discovered in blood and BALF cultures in Case 2 and in sputum culture in Case 12 within 2 days before their death. E.faecium in two urine cultures was found within 8 days, while A.baumannii in BALF culture and K.pneumoniae in both BALF and blood cultures within 2 days before death of Case 3. K.pneumoniae in both BALF and blood cultures was found within 2 days before death of Case 14. mNGS testing identified PJP in 4 recipients (Case4-10) with culture-negative sepsis. They had compatible clinical syndromes and responded well to the therapy against PJ.

Ten non-PJP recipients with mNGS negative were enrolled as the control group. The Ct values of all these 10 non-PJP recipient were more than 40. These patients did not have the clinical manifestations and radiological findings of PJP. The baseline characteristics of them were presented in Table 3. All of them were diagnosed by mNGS, 9 of whom were detected through peripheral blood with 1 through the combination of blood and sputum, and the remaining 1 recipient was detected through sputum. The median age was 43.1 (range, 19-64) years. Eight participants were males. Five recipients had renal insufficiency and 2 suffered from diabetes at the admission. All patients were initially prescribed 3 maintained immunosuppressants (tacrolimus + mycophenolate mofetil + glucocorticosteroids), and additional agents of basiliximab and/or antithymocyte globulin were administrated as an induction therapy in 5 recipients. During hospitalization, 2 recipients progressed to ARDS and one died of pulmonary embolism.

A number of variables, including age, gender, severe ARDS, BDG assays at the admission, white blood cell/lymphocyte, C-reactive protein/procalcitonin at the admission, and underlying disease such as renal insufficiency and diabetes, were compared between groups of PJP ( $n=14)$ and non-PJP $(n=10)$ by univariate analysis. Only 1 non-PJP recipient who suffered from the infection caused by Candida parapsilosis had a high BDG level at the admission. As shown in Table 4, only the outcome of BDG assays, including the absolute value $(P=0.011)$ and positive rate $(P<0.001)$, was associated with the occurrence of PJP by univariate analysis, suggesting that BDG value at the admission in PJP patients was higher than that in non-PJP patients. Mortality rates between two groups were also compared by univariate analysis but no significant difference was found, although the rate was higher in PJP recipients than that in non-PJP cases $(35.7 \%$ vs. $10.0 \% ; P=0.151)$.

\section{Discussion}

PJP is a severe fungal infection and has a high prevalence in immunocompromised individuals, thus posing a huge threat to these patients. Delayed diagnosis of all invasive fungal infection associates with higher mortality [17]. Diagnosis of PJP remains challenging due to its nonspecific clinical manifestations as well as low sensitivity and specificity of current conventional diagnostic methods [2]. Up till now, the definitive diagnosis of PJP relies on microscopic examination of stained sputum smears, lung tissues or BALF samples. Wright-Giemsa and methenamine silver-stained smear are the most commonly applied methods in past decades. Fluorescence staining with monoclonal antibodies could increase the detection sensitivity to 95\% [18]. PCR and serologic biomarkers such as serum BDG or Sadenosyl methionine level were also used to increase the PJP diagnostic rate in recent years $[1,19]$. However, the efficiency of serum BDG test for diagnosing PJP is controversial. Some studies claimed that it lacked sensitivity and specificity [1,2], while in 3 metaanalyses, it was demonstrated to have a sensitivity of $91 \%$ to $96 \%$, which is similar to the $92.9 \%(13 / 14)$ sensitivity of BDG in our present study at the admission [20-22]. We also found that the value of BDG assays at the admission was higher and was more likely positive in PJP patients than that in non-PJP patients by univariate analysis, suggesting the high sensitivity of BDG assays for PJP once again.

Compared to PCR and other conventional diagnostic methods, mNGS is a comprehensive approach, allowing sequence-based identification of all potential pathogenic microbes in clinical samples with minimized turn-around time of less than 48 hours [23,24]. To date, there have been several reports on successful use of mNGS to diagnose pulmonary infections involving PJ, with two of them reporting that mNGS is more sensitive than conventional methods (non-PCR based) [1,2,9-12]. What's more, mNGS is able to detect organisms in the setting of effective treatment, which was proved by our present study where Case 2 and 5 had received 11 and 13 days of active therapy against PJ prior to the collection of BALF sample and the fourth blood sample for mNGS testing, respectively [12]. 
PJP has been confirmed in 4 cases by mNGS in peripheral blood rather than respiratory samples in only 2 previous studies $[1,12]$. Although PJ almost exclusively inhabits the human lungs, pieces of PJ could penetrate through respiratory infectious site and circulate into peripheral blood, especially in immune-suppressed patients, thus blood PJ sequence reads can diagnose PJP [1,6]. Furthermore, there were only two studies involving 2 RTRs which utilized mNGS to detect BALF samples and find PJ $[1,2]$. Herein we found that mNGS successfully detected PJ in 10 out of 11 PJP who provided blood samples, verified by PJ PCR, highlighting the value of mNGS of blood in diagnosing PJP. In addition, obtaining high-quality blood samples is easier than BALF samples. However, with the limit of sample size and lack of control group, larger clinical trials investigation on evaluating blood mNGS for PJP diagnosis among RTRs are necessary.

The mean time interval between the onset and diagnosis of/the available therapy against PJP in died group was substantially longer than survival group. Furthermore, in our present study, mNGS testing rapidly identified PJP diagnosis and effectively guide the therapy against PJ in 7 recipients with culture-negative pneumonia. In addition, mNGS revealed the frequent combined infection of PJ with cytomegalovirus or Torque teno virus. Torque teno virus belongs to Anelloviridae family and is considered to be a marker of heavy immunodeficiency and lacks pathogenic potential and relevant clinical manifestation so far [12,25].

In conclusion, the incidence of PJP was high, with 14 cases occurring in RTRs over less than 2 year-period in our center. This study supports the value of mNGS in guiding early treatment for PJP and helping exclusion of infection with minimized turn-around time and improved sensitivity and specificity in diagnosing PJP, even indetecting organisms in the setting of effective treatment. mNGS can improve the outcome of RTRs with PJP since the longer interval between the onset and diagnosis of/the available therapy against PJP in died group. Moreover, mNGS showed great diagnostic performance in multiple organisms. mNGS of blood samples could be an alternative choice particularly for patients with pneumonia of unknown etiology in whom bronchoscopy or biopsy for tissue diagnosis is not feasible. This study also highlights the sensitivity of $\beta$-D-glucan assays for PJP. PJP often co-occurs with cytomegalovirus or Torque teno virus infections, making them alerts of PJP.

\section{Declarations}

\section{Funding}

This work was support by the Science and Technology Department of Hunan Province, China (grant 2020JJ4851).

\section{Conflict of interest}

The authors declare that they have no conflicts of interest.

\section{Availability of data and material}

The data that support the findings of this study are available within the present paper.

\section{Authors' contributions}

ZF and WQQ participated in research design and drafted the manuscript. CJ, HH, and WQQ participated in patient enrollment. RXM performed the PCR analyses. ZF and CJ performed the statistics. LRJ participated in the test of the mNGS. All authors participated in the writing and revision of the manuscript and accepted the final version.

\section{References}

1. Zhang Y, Ai JW, Cui P, et al. A cluster of cases of Pneumocystis pneumonia identified by shotgun metagenomics approach. J Infect 2019;78:158-69.

2. Jie Chen,Ting He,Xiujun Li,et al. Metagenomic Next-Generation Sequencing in Diagnosis of a Case of Pneumocystis jirovecii Pneumonia in a Kidney Transplant Recipient and Literature Review. Infect Drug Resist 2020;13:2829-36.

3. Le Gal S, Toubas D, Totet A, et al. Pneumocystis infection outbreaks in organ transplantation units in France: a nation-wide survey. Clin Infect Dis 2020;70:2216-20.

4. de Boer MG, de Fijter JW, Kroon FP. Outbreaks and clustering of Pneumocystis pneumonia in kidney transplant recipients: a systematic review. Med Mycol 2011;49:673-80. 
5. Yiannakis EP, Boswell TC. Systematic review of outbreaks of Pneumocystis jirovecii pneumonia: evidence that P. jirovecii is a transmissible organism and the implications for healthcare infection control. J Hosp Infect 2016; 93:1-8.

6. Ma L, Cisse $\mathrm{OH}$, Kovacs JA. A molecular window into the biology and epidemiology of Pneumocystis spp. Clin Microbiol Rev 2018;31:e00009-18.

7. Del Corpo O, Butler-Laporte G, Sheppard DC, et al. Diagnostic accuracy of serum (1-3)- $\beta$ - D-glucan for Pneumocystis jirovecii pneumonia: a systematic review and meta-analysis. Clin Microbiol Infect 2020;S1198-743X (20)30301-3.

8. Summah $\mathrm{H}$, Zhu YG, Falagas $M E$, et al. Use of real-time polymerase chain reaction for the diagnosis of Pneumocystis pneumonia in immunocompromised patients: a meta-analysis. Chin Med J (Engl) 2013;126:1965-73.

9. Wang J, Han Y, Feng J. Metagenomic next-generation sequencing for mixed pulmonary infection diagnosis. BMC Pulm Med 2019;19:252.

10. Irinyi L, Hu Y, Hoang MTV, et al. Long-read sequencing based clinical metagenomics for the detection and confirmation of Pneumocystis jirovecii directly from clinical specimens: a paradigm shift in mycological diagnostics. Med Mycol 2019:myz109.

11. Li Y, Sun B, Tang X, et al. Application of metagenomic next-generation sequencing for bronchoalveolar lavage diagnostics in critically ill patients. Eur J Clin Microbiol Infect Dis 2020;39:369-74.

12. Camargo JF, Ahmed AA, Lindner MS, et al. Next-generation sequencing of microbial cell-free DNA for rapid noninvasive diagnosis of infectious diseases in immunocompromised hosts. F1000Res 2019;8:1194.

13. Kasper D, Fauci A. Harrison's Infectious Diseases, 3/E. McGraw-Hill Medical, 2016.

14. Jorgensen J H. Manual of Clinical Microbiology, 11th Edition. ASM Press. 2015.

15. Langelier C, Fung M, Caldera S, et al. Detection of pneumonia pathogens from plasma cell-free DNA. Am J Respir Crit Care Med 2020;201: 491-5.

16. Miao Q, Ma Y, Wang Q, et al. Microbiological diagnostic performance of metagenomic next-generation sequencing when applied to clinical practice. Clinical Infectious Diseases 2018; 67(suppl_2): S231-40.

17. Morrell M, Fraser VJ, Kollef MH. Delaying the empiric treatment of candida bloodstream infection until positive blood culture results are obtained: a potential risk factor for hospital mortality. Antimicrob Agents Chemother 2005; 49: 3640-5.

18. Limper AH, Adenis A, Le T, et al. Fungal infections in HIV/AIDS. Lancet Infect Diseas 2017; 17: e334-43.

19. de Boer MG, Gelinck LB, van Zelst BD, et al. beta-D-glucan and S-adenosylmethionine serum levels for the diagnosis of Pneumocystis pneumonia in HIV-negative patients: a prospective study. J Infect Jan 2011; 62:93-100.

20. Onishi A, Sugiyama D, Kogata Y, et al. Diagnostic accuracy of serum 1,3-beta-D-glucan for Pneumocystis jiroveci pneumonia, invasive candidiasis, and invasive aspergillosis: systematic review and meta-analysis. J Clin Microbiol 2012;50:7-15.

21. Karageorgopoulos DE, Qu JM, Korbila IP, Zhu YG, et al. Accuracy of beta-D-glucan for the diagnosis of Pneumocystis jirovecii pneumonia: a meta-analysis. Clin Microbiol Infect 2013;19:39-49.

22. Li WJ, Guo YL, Liu TJ, et al. Diagnosis of Pneumocystis pneumonia using serum (1-3)-beta-D-glucan: a bivariate meta-analysis and systematic review. J Thorac Dis 2015;7:2214-25.

23. Chiu CY, Miller SA. Clinical metagenomics. Nat Rev Genet 2019;20:341-55.

24. Somasekar S, Lee D, Rule J, et al. Viral Surveillance in Serum Samples From Patients With Acute Liver Failure By Metagenomic Next-Generation Sequencing. Clin Infect Dis 2017;65:1477-85.

25. Lewandowska DW, Schreiber PW, Schuurmans MM, et al. Metagenomic sequencing complements routine diagnostics in identifying viral pathogens in lung transplant recipients with unknown etiology of respiratory infection. PLoS ONE 2017; 12: e0177340.

\section{Tables}

Table 1. Baselines characteristics of 14 renal recipients with PJP. 


\begin{tabular}{|c|c|c|c|c|c|c|c|}
\hline $\begin{array}{l}\text { Case } \\
\text { no. }\end{array}$ & $\begin{array}{l}\text { Age, } \\
\text { gender }\end{array}$ & $\begin{array}{l}\text { Underlying } \\
\text { diseases }\end{array}$ & $\begin{array}{l}\text { Induction/Maintained } \\
\text { immunosuppressants }\end{array}$ & $\begin{array}{l}\text { Time interval } \\
\text { between } \\
\text { transplantation } \\
\text { and PJP }\end{array}$ & $\begin{array}{l}\text { Time } \\
\text { interval } \\
\text { between } \\
\text { the onset } \\
\text { and } \\
\text { diagnosis } \\
\text { of PJP(d) }\end{array}$ & $\begin{array}{l}\text { Time } \\
\text { interval } \\
\text { between } \\
\text { the onset } \\
\text { of and } \\
\text { the } \\
\text { available } \\
\text { therapy } \\
\text { against } \\
\text { PJP(d) }\end{array}$ & Outcome \\
\hline 1 & $42 \mathrm{M}$ & $\begin{array}{l}\text { Severe ARDS; } \\
\text { RT; } \\
\text { Renal } \\
\text { insufficiency; } \\
\text { Diabetes }\end{array}$ & $\begin{array}{l}\text { Baliximab+ATG/ } \\
\text { tacrolimus+MMF+ Pred }\end{array}$ & $>7$ mons & 40 & 20 & Died \\
\hline 2 & $19 \mathrm{~F}$ & $\begin{array}{l}\text { Severe ARDS; } \\
\text { Septic shock; } \\
\text { RT }\end{array}$ & Baliximab/tacrolimus+MMF+Pred & $>7$ mons & 21 & 8 & Died \\
\hline 3 & $54 \mathrm{~F}$ & $\begin{array}{l}\text { Severe ARDS; } \\
\text { Urinary Tract } \\
\text { Infection; } \\
\text { Acute renal } \\
\text { failure; } \\
\text { RT }\end{array}$ & $\begin{array}{l}\text { ATG/tacrolimus+ } \\
\text { MMF+Pred }\end{array}$ & $>6$ mons & 18 & 17 & Died \\
\hline 4 & $43 \mathrm{~F}$ & $\begin{array}{l}\text { Pneumonia; } \\
\text { RT }\end{array}$ & $\begin{array}{l}\text { Baliximab+ATG/ } \\
\text { tacrolimus+MMF+ } \\
\text { Pred }\end{array}$ & $>4$ mons & 8 & 3 & Survival \\
\hline 5 & $50 \mathrm{M}$ & $\begin{array}{l}\text { Severe ARDS; } \\
\text { Renal } \\
\text { insufficiency; } \\
\text { RT }\end{array}$ & $\begin{array}{l}\text { Baliximab+ATG/tacrolimus } \\
\text { +MMF+Pred }\end{array}$ & $>2$ mons & 8 & 4 & Survival \\
\hline 6 & $37 \mathrm{~F}$ & $\begin{array}{l}\text { Pneumonia; } \\
\text { RT }\end{array}$ & $\begin{array}{l}\text { Baliximab+ATG/tacrolimus } \\
\text { +MMF+Pred }\end{array}$ & $>4$ mons & 9 & 4 & Survival \\
\hline 7 & $43 \mathrm{M}$ & $\begin{array}{l}\text { Pneumonia; } \\
\text { Diabetes; } \\
\text { RT }\end{array}$ & Baliximab/tacrolimus+MMF+Pred & $>3$ mons & 6 & 2 & Survival \\
\hline 8 & $30 \mathrm{M}$ & $\begin{array}{l}\text { Pneumonia; } \\
\text { Renal } \\
\text { insufficiency; } \\
\text { RT }\end{array}$ & $\begin{array}{l}\text { ATG/tacrolimus+ } \\
\text { MMF+Pred }\end{array}$ & $>3$ mons & 11 & 11 & Survival \\
\hline 9 & $33 \mathrm{M}$ & $\begin{array}{l}\text { Pneumonia; } \\
\text { Renal } \\
\text { insufficiency; } \\
\text { RT }\end{array}$ & $\begin{array}{l}\text { ATG/Tacrolimus+ } \\
\text { MMF+Pred }\end{array}$ & $>7$ mons & 6 & 5 & Survival \\
\hline 10 & $22 \mathrm{M}$ & Pneumonia; & $\begin{array}{l}\text { Tacrolimus+MMF+ } \\
\text { Pred }\end{array}$ & $>2 y r s$ & 8 & 4 & Survival \\
\hline
\end{tabular}




\begin{tabular}{|c|c|c|c|c|c|c|c|}
\hline & & $\begin{array}{l}\text { Renal } \\
\text { insufficiency; } \\
\text { RT }\end{array}$ & & & & & \\
\hline 11 & $33 \mathrm{M}$ & $\begin{array}{l}\text { Severe ARDS; } \\
\text { Renal } \\
\text { insufficiency; } \\
\text { RT }\end{array}$ & $\begin{array}{l}\text { Tacrolimus+MMF+ } \\
\text { Pred }\end{array}$ & $>2 y r s$ & 18 & 7 & Survival \\
\hline 12 & $33 \mathrm{M}$ & $\begin{array}{l}\text { Severe ARDS; } \\
\text { RT }\end{array}$ & $\begin{array}{l}\text { Baliximab+ATG/ } \\
\text { tacrolimus+MMF+ } \\
\text { Pred }\end{array}$ & $>8$ mons & 9 & 7 & Died \\
\hline 13 & $42 \mathrm{M}$ & $\begin{array}{l}\text { Pneumonia; RT; } \\
\text { VZV infection }\end{array}$ & Cyclosporin A+ MMF+Pred & $>2 y r s$ & 7 & 4 & Survival \\
\hline 14 & $46 \mathrm{M}$ & $\begin{array}{l}\text { Severe ARDS; } \\
\text { Renal } \\
\text { insufficiency; } \\
\text { Hydropericardium } \\
\text { RT }\end{array}$ & $\begin{array}{l}\text { Tacrolimus+MMF+ } \\
\text { Pred }\end{array}$ & $>5$ mons & 32 & 30 & Died \\
\hline
\end{tabular}

Abbreviations: ARDS, Acute Respiratory Distress Syndrome; ATG, antithymocyte globulin; MMF, mycophenolate mofetil; PJP, Pneumocystis jirovecii Pneumonia; RT, renal transplantation; VZV, varicella zoster virus.

Table 2. Laboratory test and metagenomic next-generation sequencing results of 14 renal recipients with PJP. 


\begin{tabular}{|c|c|c|c|c|c|c|c|}
\hline $\begin{array}{l}\text { Case } \\
\text { no. }\end{array}$ & $\begin{array}{l}\text { Sample } \\
\text { type }\end{array}$ & $\begin{array}{l}\text { Days of } \\
\text { antibiotics/ } \\
\text { antifungals } \\
\text { prior to } \\
\text { sample } \\
\text { collection }\end{array}$ & $\begin{array}{l}\text { WBC count/ } \\
\text { Total } \\
\text { lymphocyte } \\
\text { count at } \\
\text { admission } \\
\left(\times 10^{9} / \mathrm{L}\right)\end{array}$ & $\begin{array}{l}\mathrm{CRP}(\mathrm{mg} / \mathrm{L}) / \\
\mathrm{PCT}(\mathrm{ng} / \mathrm{mL}) \\
\text { at admission }\end{array}$ & $\begin{array}{l}\text { Laboratory } \\
\text { test(smear and } \\
\text { culture) }\end{array}$ & $\begin{array}{l}\beta-D- \\
\text { glucan } \\
\text { assays } \\
(\mathrm{pg} / \mathrm{ml})\end{array}$ & $\begin{array}{l}\text { Metagenomic next- } \\
\text { generation sequencing } \\
\text { results and specific } \\
\text { reads(n)/Ct values of PJ PCR }\end{array}$ \\
\hline 1 & Blood & $13 / 0$ & $7.44 / 0.17$ & $122.29 / 1.567$ & $\begin{array}{l}\text { Sputum } \\
\text { methenamine } \\
\text { silver Stained } \\
\text { smear: PJ }\end{array}$ & $\begin{array}{l}1701.4 \\
1130.9 \\
3983\end{array}$ & $\begin{array}{l}\text { Negative } \\
\text { Ct values: }>40\end{array}$ \\
\hline 2 & BALF & $11 / 11$ & $2.95 / 0.36$ & $2.56 / 0.043$ & $\begin{array}{l}\text { Blood and } \\
\text { BALF culture: } A \text {. } \\
\text { baumannii }\end{array}$ & $\begin{array}{l}160.9 \\
210.2\end{array}$ & $\begin{array}{l}\text { Human coronavirus } \\
229 \mathrm{E}(808) ; \mathrm{PJ}(3464) \\
\text { Ct values: } 25.21\end{array}$ \\
\hline 3 & Blood & $11 / 10$ & $6.95 / 1.2$ & $95.62 / 0.146$ & $\begin{array}{l}\text { Urine culture: } \\
\text { E.faecium } \\
\text { BALF culture: } A . \\
\text { baumannii and } \\
\text { K.pneumoniae; } \\
\text { Blood culture: } \\
\text { K.pneumoniae }\end{array}$ & $\begin{array}{l}280.2 \\
206 \\
1090.1 \\
1215.7 \\
529.1 \\
147.7 \\
115.2\end{array}$ & $\begin{array}{l}\text { CMV (74); PJ(48). } \\
\text { Ct values:35.40 }\end{array}$ \\
\hline 4 & $\begin{array}{l}\text { Blood; } \\
\text { Sputum }\end{array}$ & $5 / 3$ & $10.91 / 0.37$ & $60.21 / 0.452$ & $\begin{array}{l}\text { Sputum culture: } \\
\text { Negative }\end{array}$ & $\begin{array}{l}412.9 \\
491.9 \\
1077.2 \\
782.7\end{array}$ & $\begin{array}{l}\text { Blood: PJ(24); TTV(20) } \\
\text { Sputum: PJ(488); HHV- } \\
\text { 7(538). } \\
\text { Ct values: } 27.49 \text { (Sputum); } \\
\text { 34.28(Blood) }\end{array}$ \\
\hline 5 & Blood & $1 / 0$ & $10.05 / 0.53$ & $70.48 / 0.094$ & $\begin{array}{l}\text { Blood and urine } \\
\text { culture: Negative }\end{array}$ & $\begin{array}{l}85.6 \\
481.8 \\
856.4 \\
1217 \\
2019 \\
1477.9 \\
412 \\
155.4\end{array}$ & $\begin{array}{l}\text { Blood 1: PJ(55);CMV (37); } \\
\text { TTV (10) } \\
\text { Blood 2: PJ(260);CMV(4) } \\
\text { Blood 3: PJ(33);CMV (91) } \\
\text { Blood 4: PJ(8);CMV(144); } \\
\text { TTV (78) } \\
\text { Blood 5: CMV(149). } \\
\text { Ct values:36.50(Blood 1) }\end{array}$ \\
\hline 6 & Blood & $3 / 3$ & $7.53 / 0.33$ & $81.73 / 0.233$ & $\begin{array}{l}\text { Blood culture: } \\
\text { Negative }\end{array}$ & $\begin{array}{l}367.5 \\
559.7 \\
195.5 \\
40.8\end{array}$ & $\begin{array}{l}\text { PJ(9); BKV(294); } \\
\text { TTV (16) } \\
\text { Ct values: } 36.23\end{array}$ \\
\hline 7 & Blood & $4 / 1$ & $3.62 / 0.38$ & $14.69 / 0.096$ & $\begin{array}{l}\text { Blood culture: } \\
\text { Negative }\end{array}$ & $\begin{array}{l}531.3 \\
1320.7 \\
299.7\end{array}$ & $\begin{array}{l}\text { PJ(41); TTV (15); } \\
\text { Candida parapsilosis(8) } \\
\text { Ct values:34.92 }\end{array}$ \\
\hline 8 & Sputum & $2 / 2$ & $8.84 / 0.58$ & $33.08 / 0.221$ & $\begin{array}{l}\text { Sputum culture: } \\
\text { Negative }\end{array}$ & 613.5 & $\begin{array}{l}\text { PJ(29751); HHV-7(554); TTV } \\
\text { (8); }\end{array}$ \\
\hline
\end{tabular}

Page 10/13 


\begin{tabular}{|c|c|c|c|c|c|c|c|}
\hline & & & & & & 916.9 & \multirow[t]{6}{*}{ Ct values:25.14 } \\
\hline & & & & & & 2222.1 & \\
\hline & & & & & & 485.7 & \\
\hline & & & & & & 128.4 & \\
\hline & & & & & & 167.3 & \\
\hline & & & & & & 60.2 & \\
\hline \multirow[t]{4}{*}{9} & \multirow[t]{4}{*}{ Blood } & \multirow[t]{4}{*}{$1 / 0$} & \multirow[t]{4}{*}{$16.41 / 1.57$} & \multirow[t]{4}{*}{$14.44 / 0.063$} & \multirow{4}{*}{$\begin{array}{l}\text { Blood culture: } \\
\text { Negative }\end{array}$} & 366.9 & $\mathrm{PJ}(7)$ \\
\hline & & & & & & 166.4 & Ct values:38.42 \\
\hline & & & & & & 40.5 & \\
\hline & & & & & & 37.2 & \\
\hline \multirow[t]{3}{*}{10} & \multirow[t]{3}{*}{ Blood } & \multirow[t]{3}{*}{$3 / 2$} & \multirow[t]{3}{*}{$9.65 / 0.8$} & \multirow[t]{3}{*}{$5.87 / 0.095$} & \multirow{3}{*}{$\begin{array}{l}\text { Blood culture: } \\
\text { Negative }\end{array}$} & 345 & PJ(128); CMV (90). \\
\hline & & & & & & 812.6 & Ct values:34.41 \\
\hline & & & & & & 99.3 & \\
\hline \multirow[t]{6}{*}{11} & \multirow[t]{6}{*}{ BALF } & \multirow[t]{6}{*}{$9 / 9$} & \multirow[t]{6}{*}{$17.09 / 0.7$} & \multirow[t]{6}{*}{$41.13 / 0.47$} & \multirow{2}{*}{$\begin{array}{l}\text { Sputum culture: } \\
\text { Pseudomonas } \\
\text { putida }\end{array}$} & 1720.9 & PJ(866); \\
\hline & & & & & & 40.4 & Pseudomonas putida(8093); \\
\hline & & & & & \multirow{4}{*}{$\begin{array}{l}\text { Blood culture: } A \text {. } \\
\text { baumannii } \\
\text { Secretion culture: } \\
\text { Candida } \\
\text { parapsilosis }\end{array}$} & 30.2 & Candida orthopsilosis(2828); \\
\hline & & & & & & & Canalaa parapsilosis(๖๖); \\
\hline & & & & & & & HHV-1(13)】 \\
\hline & & & & & & & Ct values:28.30 \\
\hline \multirow[t]{5}{*}{12} & \multirow[t]{5}{*}{ Blood } & \multirow[t]{5}{*}{$2 / 1$} & \multirow[t]{5}{*}{$17.29 / 1$} & \multirow[t]{5}{*}{ 188.05/1.416 } & \multirow{5}{*}{$\begin{array}{l}\text { Blood and urine } \\
\text { cultures: Negative } \\
\text { Sputum culture: } A \text {. } \\
\text { baumannii }\end{array}$} & 155.4 & Blood 1: PJ(66); CMV (10); \\
\hline & & & & & & 811.3 & TTV (167); \\
\hline & & & & & & 1089.5 & Blood 2: PJ(1087); \\
\hline & & & & & & 1868.3 & Human polyomavirus $8(21)$ \\
\hline & & & & & & 289 & Ct values:33.82 \\
\hline \multirow[t]{3}{*}{13} & \multirow[t]{3}{*}{ Blood } & $6 / 1$ & $9.2 / 0.6$ & $94.68 / 0.019$ & Not available & 177.2 & Aspergillus glaucus(58); \\
\hline & & & & & & 102.6 & $\mathrm{PJ}(6) ; \mathrm{TTV}(5)$ \\
\hline & & & & & & & Ct values:38.22 \\
\hline 14 & Blood; & $1 / 1$ & $10.58 / 0.19$ & $94.81 / 0.108$ & $\begin{array}{l}\text { BALF culture: } \\
\text { enterococcus }\end{array}$ & 318.7 & $\begin{array}{l}\text { Blood:PJ(6); Human } \\
\text { polvomavirus 1(417): TTV(5) }\end{array}$ \\
\hline & BALF & & & & faecium; & 135 & 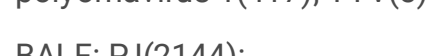 \\
\hline & & & & & baumannii & 531.6 & $\begin{array}{l}\text { Haemophilus parainfluenzae } \\
\text { (149): Mycoplasma orale }\end{array}$ \\
\hline & & & & & Blood culture: & & (1767); HHV-7(20); TTV(18). \\
\hline & & & & & & & $\begin{array}{l}\text { Ct values: } 25.43 \text { (BALF); } \\
\text { 37.98(Blood) }\end{array}$ \\
\hline
\end{tabular}

Abbreviations: BALF, bronchoalveolar lavage fluid; BKV, BK virus; CMV, cytomegalovirus; CRP, C-reactive protein; HHV, human herpesvirus; PJ, Pneumocystis_jirovecii, PJP, Pneumocystis jirovecii Pneumonia; PCT, procalcitonin; TTV, Torque teno virus; WBC, white blood cell.

Table 3. Baselines characteristics of 10 renal recipients with non-PJP. 


\begin{tabular}{|c|c|c|c|c|c|c|c|}
\hline $\begin{array}{l}\text { Case } \\
\text { no. }\end{array}$ & $\begin{array}{l}\text { Age, } \\
\text { gender }\end{array}$ & $\begin{array}{l}\text { Underlying } \\
\text { diseases }\end{array}$ & $\begin{array}{l}\text { Induction/ } \\
\text { Maintained } \\
\text { immunosuppressants }\end{array}$ & $\begin{array}{l}\text { Time interval } \\
\text { between } \\
\text { transplantation } \\
\text { and non-PJP }\end{array}$ & Culture result & $\begin{array}{l}\text { Sample/ } \\
\text { Metagenomic next- } \\
\text { generation } \\
\text { sequencing results } \\
\text { and specific reads }(\mathrm{n})\end{array}$ & Outcome \\
\hline 1 & $64 \mathrm{~F}$ & $\begin{array}{l}\text { Pneumonia; } \\
\text { RT; } \\
\text { Renal } \\
\text { insufficiency }\end{array}$ & $\begin{array}{l}\text { ATG/tacrolimus+ } \\
\text { MMF+Pred }\end{array}$ & $>2$ mons & Not available & $\begin{array}{l}\text { Blood/Mycobacterium } \\
\text { kansasii(125) }\end{array}$ & Survival \\
\hline 2 & $43 \mathrm{M}$ & $\begin{array}{l}\text { Pneumonia; } \\
\text { RT }\end{array}$ & $\begin{array}{l}\text { Tacrolimus+MMF+ } \\
\text { Pred }\end{array}$ & $>1 \mathrm{yrs}$ & $\begin{array}{l}\text { Sputum } \\
\text { culture: } \\
\text { Negative }\end{array}$ & $\begin{array}{l}\text { Sputum/Neisseria } \\
\text { Meningitidis(7) }\end{array}$ & Survival \\
\hline 3 & $49 M$ & $\begin{array}{l}\text { Pneumonia; } \\
\text { RT; } \\
\text { Severe } \\
\text { anemia }\end{array}$ & $\begin{array}{l}\text { ATG/tacrolimus+ } \\
\text { MMF+Pred }\end{array}$ & $>1$ mon & Not available & $\begin{array}{l}\text { Blood/CMV } \\
\text { (193); Human } \\
\text { alphaherpes- } \\
\text { virus1(10) }\end{array}$ & Survival \\
\hline 4 & $19 \mathrm{~F}$ & $\begin{array}{l}\text { Pneumonia; } \\
\text { Chronic } \\
\text { renal } \\
\text { allograft } \\
\text { dysfunction }\end{array}$ & $\begin{array}{l}\text { ATG/tacrolimus+ } \\
\text { MMF+Pred }\end{array}$ & $>2 \mathrm{yrs}$ & $\begin{array}{l}\text { Blood culture: } \\
\text { Negative }\end{array}$ & $\begin{array}{l}\text { Blood/EBV } \\
(165)\end{array}$ & Survival \\
\hline 5 & $56 \mathrm{M}$ & $\begin{array}{l}\text { Severe } \\
\text { ARDS; } \\
\text { Chronic } \\
\text { renal } \\
\text { allograft } \\
\text { dysfunction; } \\
\text { Diabetes; } \\
\text { Pulmonary } \\
\text { embolism }\end{array}$ & $\begin{array}{l}\text { Tacrolimus+MMF+ } \\
\text { Pred }\end{array}$ & $>3$ mons & $\begin{array}{l}\text { Blood and } \\
\text { sputum } \\
\text { culture: } \\
\text { Negative }\end{array}$ & $\begin{array}{l}\text { Blood/CMV } \\
\text { (185) }\end{array}$ & Died \\
\hline 6 & $54 \mathrm{M}$ & $\begin{array}{l}\text { Pneumonia; } \\
\text { RT; } \\
\text { Renal } \\
\text { insufficiency; } \\
\text { Diabetes }\end{array}$ & $\begin{array}{l}\text { Baliximab+ATG/ } \\
\text { tacrolimus+MMF+ } \\
\text { Pred }\end{array}$ & $>5$ mons & $\begin{array}{l}\text { Sputum } \\
\text { culture: } \\
\text { Negative }\end{array}$ & $\begin{array}{l}\text { Blood/TTV } \\
\text { (993); CMV(6); } \\
\text { Candida } \\
\text { parapsilosis(3) }\end{array}$ & Survival \\
\hline 7 & $33 \mathrm{M}$ & $\begin{array}{l}\text { ARDS; } \\
\text { RT }\end{array}$ & $\begin{array}{l}\text { Tacrolimus+MMF+ } \\
\text { Pred }\end{array}$ & $>5$ mons & $\begin{array}{l}\text { Blood culture: } \\
\text { Negative }\end{array}$ & $\begin{array}{l}\text { Blood/ } \\
\text { pseudomonas } \\
\text { aeruginosa(6) }\end{array}$ & Survival \\
\hline 8 & $29 M$ & $\begin{array}{l}\text { Pneumonia; } \\
\text { RT }\end{array}$ & $\begin{array}{l}\text { Baliximab+ATG/ } \\
\text { tacrolimus+MMF+ } \\
\text { Pred }\end{array}$ & $>1 \mathrm{wk}$ & $\begin{array}{l}\text { Blood culture: } \\
\text { pseudomonas } \\
\text { aeruginosa }\end{array}$ & $\begin{array}{l}\text { Blood/ } \\
\text { pseudomonas } \\
\text { aeruginosa(226) }\end{array}$ & Survival \\
\hline 9 & $52 \mathrm{M}$ & $\begin{array}{l}\text { Pneumonia; } \\
\text { RT; } \\
\text { Gout }\end{array}$ & $\begin{array}{l}\text { Tacrolimus+MMF+ } \\
\text { Pred }\end{array}$ & $>2 \mathrm{yrs}$ & $\begin{array}{l}\text { Blood and } \\
\text { sputum } \\
\text { culture: } \\
\text { Negative }\end{array}$ & $\begin{array}{l}\text { Blood/ } \\
\text { pseudomonas } \\
\text { aeruginosa(7) }\end{array}$ & Survival \\
\hline 10 & $32 \mathrm{M}$ & $\begin{array}{l}\text { Pneumonia; } \\
\text { Renal } \\
\text { insufficiency; } \\
\text { RT }\end{array}$ & $\begin{array}{l}\text { Tacrolimus+MMF+ } \\
\text { Pred }\end{array}$ & $>11$ mons & $\begin{array}{l}\text { Blood culture: } \\
\text { Negative }\end{array}$ & $\begin{array}{l}\text { Blood/TTV(13). } \\
\text { Sputum/ } \\
\text { Streptococcus } \\
\text { Mitis(2153); }\end{array}$ & Survival \\
\hline
\end{tabular}

Page $12 / 13$ 
Abbreviations: ARDS, Acute Respiratory Distress Syndrome; ATG, antithymocyte globulin;BALF, bronchoalveolar lavage fluid; CMV, cytomegalovirus; EBV, EB virus; MMF, mycophenolate mofetil; PJP, Pneumocystis jirovecii Pneumonia; Pred, prednisone; RT, renal transplantation; TTV, Torque teno virus.

Table 4. Univariate analysis of Characteristics between PJP and non-PJP groups.

\begin{tabular}{|llll|}
\hline Characteristics & PJP group & Non-PJP group & $P$ \\
\hline Total, $\mathrm{n}(\%)$ & $14(58.3)$ & $10(41.7)$ & \\
\hline Univariate analysis & & & \\
\hline Age $(\mathrm{yrs})$ & $37.6 \pm 10.0$ & $43.1 \pm 14.3$ & 0.262 \\
\hline Male gender, $\mathrm{n}(\%)$ & $10(71.4)$ & $8(80.0)$ & 0.633 \\
\hline Severe ARDS, $\mathrm{n}(\%)$ & $7(50.0)$ & $1(10.0)$ & 0.134 \\
\hline Renal insufficiency, $\mathrm{n}(\%)$ & $7(50.0)$ & $4(40.0)$ & 0.628 \\
\hline Diabetes, $\mathrm{n}(\%)$ & $2(14.3)$ & $2(20.0)$ & 0.711 \\
\hline BDG assays at the admission, mean $\mathrm{pg} / \mathrm{ml} \pm \mathrm{SD}$ & $517.0 \pm 526.3$ & $42.5 \pm 44.8$ & 0.011 \\
\hline BDG assays positive at the admission & $13(92.9)$ & $1(10.0)$ & $<0.001$ \\
\hline WBC at the admission, mean value $\pm S D\left(\times 10^{9} / \mathrm{L}\right)$ & $9.9 \pm 4.5$ & $12.2 \pm 14.4$ & 0.556 \\
\hline Lymphocyte at the admission, mean value $\pm S D\left(\times 10^{9} / \mathrm{L}\right)$ & $0.6 \pm 0.4$ & $0.9 \pm 0.6$ & 0.147 \\
\hline CRP at the admission, mean mg/L $\pm S D$ & $65.7 \pm 52.3$ & $37.9 \pm 49.8$ & 0.188 \\
\hline PCT at the admission, mean $\mathrm{ng} / \mathrm{ml} \pm \mathrm{SD}$ & $0.4 \pm 0.5$ & $10.7 \pm 31.4$ & 0.209 \\
\hline Death, $\mathrm{n}(\%)$ & $5(35.7)$ & $1(10.0)$ & 0.151 \\
\hline
\end{tabular}

ARDS, Acute Respiratory Distress Syndrome; BDG,B-D-glucan; CRP, C-reactive protein; PCT, procalcitonin; PJP, Pneumocystis jirovecii Pneumonia; SD, standard deviation; WBC, white blood cell. 